\title{
Harvest of Lettuce from Verticillium-Infested Fields Has Little Impact on Postharvest Quality
}

\author{
Krishna D. Puri, ${ }^{1}$ Gary E. Vallad, ${ }^{2}$ Qing-Ming Qin, ${ }^{3}$ Ryan J. Hayes, ${ }^{4}$ and Krishna V. Subbarao ${ }^{1, \dagger}$ \\ ${ }^{1}$ Department of Plant Pathology, University of California, Davis, Salinas, CA 93905, U.S.A.; ${ }^{2}$ Plant Pathology Department, \\ Gulf Coast Research and Education Center, IFAS, University of Florida, Wimauma, FL 33598, U.S.A.; ${ }^{3}$ Department of Plant \\ Protection, Jilin University, Changchun, Jilin 130062, China; and ${ }^{4}$ United States Department of Agriculture-Agricultural \\ Research Service (USDA-ARS), Salinas, CA 93950, U.S.A.
}

\begin{abstract}
Verticillium wilt of lettuce, caused by the soilborne pathogen Verticillium dahliae, poses a serious threat to the California lettuce industry. Knowledge of disease development and its impact on postharvest marketability would facilitate better management of the affected fields. This study investigated postharvest marketability of 22 lettuce varieties harvested from two Verticillium-infested commercial lettuce fields in Salinas and Watsonville, CA, in 2005 using a randomized complete block design. Periodic sampling to monitor disease in several crisphead varieties in the field demonstrated that root symptoms developed quickly at later stages of heading, followed by the onset of foliar symptoms as the crop reached harvest maturity. Harvested marketable heads were vacuum cooled soon after harvest to about $4^{\circ} \mathrm{C}$ and maintained at this temperature in commercial coolers. The impact of $V$. dahliae on postharvest marketability was

assessed based on the percentage of heads per case deemed marketable following 1, 2, and 3 weeks of refrigerated storage. Across both field experiments, the average disease incidence and postharvest marketability ranged from 4.2 to $87.5 \%$ and from 69.4 to $100.0 \%$, respectively, among lettuce types and varieties. The Pearson correlation analysis detected no significant relationship between disease incidence and postharvest marketability across all varieties tested $(r=0.041, P=0.727)$, or within lettuce types, even though $V$. dahliae was recovered from $34 \%$ of the plants harvested, and recovery ranged from 0 to $73.3 \%$ for $V$. dahliae and from 10 to $91.7 \%$ for non- $V$. dahliae (V. isaacii or $V$. klebahnii) species. These findings demonstrate that growers can harvest lettuce from an infested field before foliar symptoms develop with negligible impact by Verticillium spp. on postharvest marketability or quality.
\end{abstract}

Verticillium wilt primarily caused by Verticillium dahliae Kleb is a serious problem on lettuce in California and other crops globally. Since its first identification on lettuce near Watsonville in 1995, the disease has spread to other prime lettuce production regions of the Salinas Valley (Atallah et al. 2012; Subbarao et al. 1997), the salad capital of the United States. Lettuce (Lactuca sativa L.), which was previously considered immune to the wilt disease, is now significantly compromised by the introduction of host-adapted isolates of V. dahliae (Atallah et al. 2011; Cirulli et al. 2010). Verticillium wiltaffected fields might suffer near total crop losses. Symptoms generally begin with wilting of basal leaves that have angular ( $\mathrm{V}$-shaped) chlorotic areas along the margins. Often, the veins of lower senescent leaves are filled with microsclerotia, and this characteristic is unique to lettuce. Plants might show severe stunting and developmental abnormalities. Characteristically, prior to the onset of foliar symptoms, a severe vascular discoloration in the tap root occurs (Vallad et. al. 2006). Despite $V$. dahliae being the primary etiological species prevalent in coastal California, other species, including $V$. isaacii and $V$. klebahnii, have been recovered from agricultural soils and crops in coastal California (Qin et al. 2008; Short et al. 2015). Recent phylogenetic analyses provide strong evidence that the species previously described as V. tricorpus (Qin et al. 2008) is either V. isaacii or V. klebahnii (Inderbitzin et al. 2011). These species are morphologically indistinguishable, although phylogenetically distinct (Inderbitzin et al. 2011). Pathogenicity analysis of $V$. isaacii or V. klebahnii on lettuce, eggplant, artichoke,

${ }^{\dagger}$ Corresponding author: Krishna V. Subbarao;

E-mail: kvsubbarao@ucdavis.edu

Funding: This research was supported by the California Leafy Greens Research Board.

Accepted for publication 9 September 2018.

() 2019 The American Phytopathological Society cauliflower, strawberry, spinach, pepper, and tomato determined them to be as much or less virulent and destructive than $V$. dahliae depending on the crop inoculated (Gurung et al. 2015). One isolate of $V$. isaacii caused severe vascular discoloration in crisphead lettuce cultivar Salinas equivalent to $V$. dahliae (Gurung et al. 2015). Powell et al. (2013) isolated pathogenic isolates of $V$. isaacii from commercial lettuce plants, although they reported them as the morphospecies $V$. tricorpus. Even though $V$. dahliae is the most important pathogen causing Verticillium wilt on lettuce and other coastal California crops, select isolates of $V$. isaacii and $V$. klebahnii also can cause significant problems on some crops including lettuce (Gurung et al. 2015; Qin et al. 2008).

Lettuce is the fifth highest ranked revenue generating commodity in California with an estimated value of $\$ 1.96$ billion in 2016 (https:// www.cdfa.ca.gov/statistics/). Within the United States, lettuce is almost exclusively consumed raw as the main ingredient of salads or as a sandwich filling. Internationally, other uses are known. The stems may be eaten cooked or raw, and oil can be extracted from the seed of specific types of lettuce (Hayes 2017a). Lettuce ranked only second to potatoes in per capita annual consumption in the United States, with an average of $9.57 \mathrm{~kg}$ (55\% of which includes head lettuce) per person in 2015 (https://www.ers.usda.gov). Lettuce varieties can be categorized into a different market or horticulture types based primarily on leaf shape, rosette architecture, and the tendency for head formation (Hayes 2017a). There are six edible forms that include crisphead (iceberg and Batavia), romaine, butterhead, leaf, Latin, and stem (Hayes 2017a). The production of all lettuce types in the United States totaled 3.7 billion kilograms in 2016 (https:// www.agmrc.org/).

The sensorial and nutritional quality of lettuce declines rapidly after harvest, and a considerable loss occurs during storage owing to its highly perishable nature (Tian et al. 2014). Postharvest losses of up to $35 \%$ are anticipated in lettuce in some developing countries, whereas other leafy vegetables generally endure postharvest losses of 2 to 23\% (Harvey 1978; cited in Kader 2005). These losses might be both quantitative and qualitative and generally happen between harvest and consumption (Kader 2005). Both heads and cut leaves are highly 
sensitive to high temperature, low humidity, and exposure to ethylene (Chandra et al. 2009; Gross et al. 2016). The storage life decreases proportionally as the storage temperature and length increase (Lin and Hall 2003; Nam and Kwon 1999). Differences in shelf life also exist among horticultural types of lettuce. Romaine lettuce that has been cut or damaged will discolor more rapidly than crisphead lettuce. The density of the heads can also affect storage and shelf life even within the same variety. To minimize such damage, harvested heads are vacuum cooled within hours after harvest and maintained at storage temperatures as close to $1^{\circ} \mathrm{C}$ as possible with 98 to $100 \%$ relative humidity. The head types are better adapted to prolonged storage and can be stored safely for about 4 weeks, but the shelf life is reduced by half at $5^{\circ} \mathrm{C}$ (Gross et al. 2016). Heads become unmarketable with the appearance of browning, pinking, or water-soaking and bruising followed by the occurrence of limp and slimy tissue (Hayes and Liu 2008; Martínez-Sánchez et al. 2012; Zhang et al. 2007). However, fresh cut lettuce has a short shelf life of 5 to 6 days (Wagstaff et al. 2010), but the shelf life of ready-toeat prepackaged salad in plastic bags can be as long as 2 to 3 weeks.

Postharvest losses and microbial contamination in lettuce or other crops could be facilitated by preexposure to pathogenic microorganisms in the field (Heaton and Jones 2008; Leff and Fierer 2013). Postharvest physiological disorders in lettuce include the expression of a complex set of metabolic processes in response to preexposed environmental factors such as high temperature in the field, or owing to unfavorable conditions during storage. Brown stain, pink rib, and tipburn are major disorders of mature or postharvest lettuce (Hayes 2017b; Liu 2017; Raid 2004). Other physiological disorders include butt discoloration, internal rib necrosis, and rusty-brown discoloration (Hayes 2017b; Moline and Lipton 1987). Brown stain and russet spotting are caused by excess $\mathrm{CO}_{2}$ and ethylene, respectively, whereas tipburn is associated with localized calcium deficiencies in the tissues that develop the disorder (Saltveit et al. 2017). Conditions that promote rapid growth or reduce calcium supply to leaves likely contribute to these disorders. Overall, lettuce varieties can differ in rates of decay, proneness to injuries, and tolerance to higher levels of $\mathrm{CO}_{2}$ and ethylene (Saltveit et al. 2017).

Bacterial soft rot, one of the most serious concerns during postharvest storage, often starts on injured leaves of lettuce and causes severe tissue breakdown. Soft rot is also facilitated by mechanical damage during harvesting and packaging, exposure of lettuce heads to extreme freezing and high-temperature conditions, or fungal infections and physiological disorders (Liu 2017). Infections by Botrytis cinerea and Sclerotinia spp. also result in severe tissue breakdown. Crisphead lettuce is generally more resistant to postharvest diseases than leaf lettuce (Liu 2017). Trimming and storing lettuce at $1{ }^{\circ} \mathrm{C}$ greatly reduces the severity of postharvest diseases. In the case of Verticillium wilt, it is not clear whether disease symptoms can progress during postharvest storage and whether $V$. dahliae infection impacts market quality. Lettuce infected with $V$. dahliae often remains symptomless until the plant reaches vegetative maturity, which coincides with harvest, after which disease symptoms develop rapidly (Subbarao et al. 2017; Vallad and Subbarao 2008). However, whether the disease on symptomless but infected lettuce harvested would progress during postharvest storage and lead to tissue breakdown is unknown. Thus, the present study was conducted to investigate the impact of Verticillium wilt on postharvest marketability of lettuce varieties harvested from commercial lettuce fields infested with $V$. dahliae and also to monitor the progress of postharvest disorders, if any.

\section{Materials and Methods}

Experimental locations and lettuce varieties. Two experiments were conducted within commercial lettuce fields with a history of high Verticillium wilt incidence in Salinas and Watsonville, CA, respectively. The land preparation, seed sowing, thinning, fertilization, and pest management were conducted to commercial standards (Smith et al. 2003). The first field experiment established in Salinas consisted of eight beds on $0.6-\mathrm{m}$ bed centers of $36.5-\mathrm{m}$ length. Individual plots consisted of four adjacent 6.1-m-long beds. Seeds were sown on 13 May 2005, and seedlings were thinned to maintain a 25.4-cm plant spacing with a total 192 plants per plot. Four lettuce varieties, two each from crisphead (Sniper and Salinas 88) and romaine (Camino Real and Passport) types, were planted in a randomized complete block design (RCBD) with three replications.

The second field experiment at Watsonville consisted of 28 beds on $0.6-\mathrm{m}$ bed centers of 82.3-m length. Individual plots consisted of four adjacent 9.1-m-long beds. Seeds were sown on 7 June

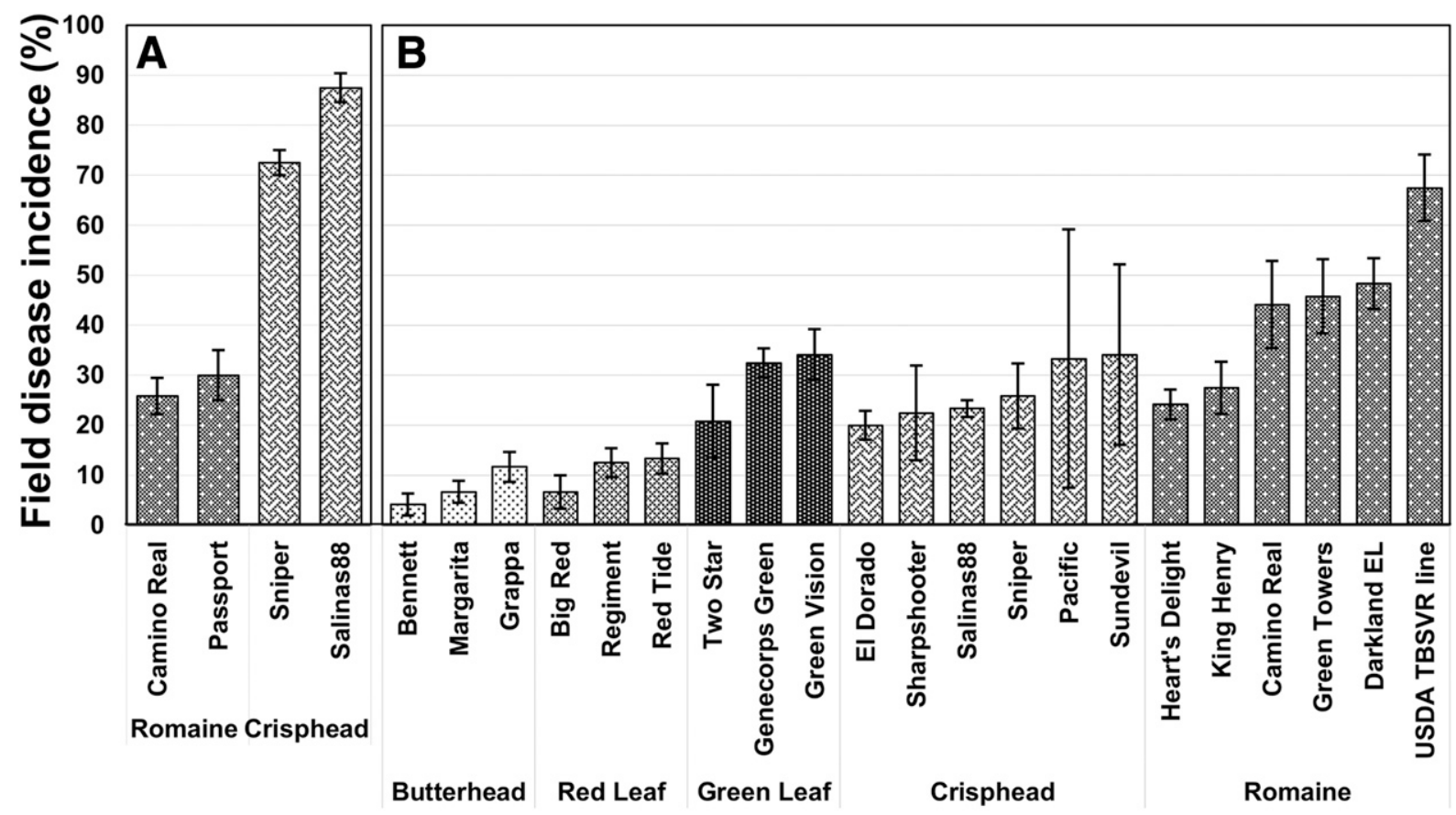

\section{Lettuce types}

Fig. 1. Verticillium wilt incidence on lettuce varieties, by horticultural type, at harvest maturity at the field sites in Salinas (A) and Watsonville (B). Vertical lines above the bars indicate standard error (SE) of the means. Data represent mean \pm SE from three independent replications. 
2005 , and seedlings were thinned to maintain $25.4-\mathrm{cm}$ plant spacing with a total of 288 plants per plot. Treatments included six crisphead varieties (Sniper, Salinas 88, Pacific, Sharpshooter, El Dorado, and Sundevil), six romaine varieties (Camino Real, Heart's Delight, Green Towers, Darkland EL, King Henry, and USDA tomato bushy stunt virus resistant [TBSVR] line), three red leaf varieties (Big Red, Regiment, and Red Tide), three green leaf varieties (Two Star, Genecorps Green, and Green Vision), and three butterhead varieties (Margarita, Grappa, and Bennett). All varieties were arranged in a RCBD with three replications.

Verticillium wilt evaluation and lettuce harvest. In lettuce, the development of Verticillium wilt is linked to plant development (Vallad and Subbarao 2008). Initial aboveground symptoms of chlorosis and wilt associated with Verticillium wilt typically develop as the plant reaches vegetative maturity and transitions to reproductive growth (referred to as bolting), which coincides with market maturity. However, even prior to the development of visible aboveground symptoms, infected plants exhibit symptoms of vascular discoloration within crown and root tissues (Subbarao et al. 2017; Vallad and Subbarao 2008). To monitor disease development at the time of field harvest prior to the development of visible wilt symptoms, plants were randomly uprooted and were cut longitudinally through the crown and taproot to observe root discoloration as the plants approached market maturity.

Immediately prior to the harvest of each horticultural lettuce type, a subset of 20 plants in each plot was uprooted, cut longitudinally from the crown through the taproot, and rated for early symptoms of Verticillium wilt based on the total number of plants with characteristic vascular discoloration (Vallad et al. 2006). Following disease evaluation, lettuce heads were harvested by a commercial harvest crew and packed into boxes of 24 heads. Lettuce plants exhibiting moderate to severe symptoms of wilting, deemed unacceptable by industry standards, were avoided by the harvest crew and not included in any postharvest evaluations. Three boxes each containing 24 heads of lettuce were harvested per replication in both locations. The harvested boxes were labeled, arranged on pallets, vacuum cooled, and stored at $4{ }^{\circ} \mathrm{C}$ in a commercial lettuce cooling facility in Salinas, CA. Each box was subsequently used to evaluate postharvest marketability and Verticillium wilt symptoms at 1 and 2 weeks after harvest for green leaf, red leaf, and butterhead lettuce varieties and at 1 to 3 weeks after storage for crisphead and romaine lettuce by following the commercially accepted shelf life evaluation thresholds (Cantwell and Suslow 2002). In cases where insufficient plants were available for each postharvest evaluation, the initial

Table 1. Verticillium wilt incidence and the postharvest marketability of lettuce variety of various horticultural types in Salinas and Watsonville, CA

\begin{tabular}{|c|c|c|c|c|c|}
\hline \multirow[b]{2}{*}{ Horticultural type/location/varieties } & \multirow[b]{2}{*}{ Field disease incidence $(\%)^{y}$} & \multicolumn{3}{|c|}{ Postharvest marketable heads (\%) } & \multirow[b]{2}{*}{$P_{\text {TIME }}{ }^{\mathrm{z}}$} \\
\hline & & Week 1 & Week 2 & Week 3 & \\
\hline \multicolumn{6}{|l|}{ Romaine, Salinas } \\
\hline Camino Real & 25.8 & $\ldots$ & 98.6 & 77.8 & 0.0788 \\
\hline Passport & 30.0 & $\ldots$ & 100 & 69.4 & 0.0184 \\
\hline$P$ & 0.2999 & & 0.8966 & 0.4445 & \\
\hline \multicolumn{6}{|l|}{ Crisphead, Salinas } \\
\hline Salinas 88 & 87.5 & 98.6 & 97.2 & 79.2 & $<0.0001$ \\
\hline Sniper & 72.5 & 100 & 97.2 & 100.0 & 0.5999 \\
\hline$P$ & 0.0091 & 0.6627 & 1.0000 & $<0.0001$ & \\
\hline \multicolumn{6}{|l|}{ Butterhead, Watsonville } \\
\hline Bennett & 4.2 & $\ldots$ & $84.7 \mathrm{~b}$ & $\ldots$ & $\ldots$ \\
\hline Margarita & 6.7 & 97.2 & $97.2 \mathrm{a}$ & $\ldots$ & 1.0000 \\
\hline Grappa & 11.7 & 100 & $98.6 \mathrm{a}$ & $\ldots$ & 0.7918 \\
\hline$P$ & 0.178 & 0.5995 & 0.0412 & $\ldots$ & \\
\hline \multicolumn{6}{|l|}{ Red leaf, Watsonville } \\
\hline Big Red & $6.7 \mathrm{~b}$ & 97.2 & 98.6 & $\ldots$ & 0.7629 \\
\hline Regiment & $12.5 \mathrm{a}$ & 89 & $\ldots$ & $\ldots$ & $\ldots$ \\
\hline Red Tide & $13.3 \mathrm{a}$ & 97.2 & 94.4 & $\ldots$ & 0.549 \\
\hline$P$ & 0.0091 & 1.0000 & 0.1435 & & \\
\hline \multicolumn{6}{|l|}{ Green leaf, Watsonville } \\
\hline Two Star & 20.8 & $100 \mathrm{a}$ & 91.7 & $\ldots$ & 0.2115 \\
\hline Genecorps Green & 32.5 & $98.6 \mathrm{a}$ & 83.3 & $\ldots$ & 0.0200 \\
\hline Green Vision & 34.2 & $80.6 \mathrm{~b}$ & 80.6 & $\ldots$ & 1.0000 \\
\hline$P$ & 0.2405 & 0.0090 & 0.2418 & $\ldots$ & \\
\hline \multicolumn{6}{|l|}{ Crisphead, Watsonville } \\
\hline El Dorado & 20.0 & 100 & 95.8 & 84.7 & 0.0093 \\
\hline Sharpshooter & 22.5 & 100 & 98.6 & 80.6 & 0.0004 \\
\hline Salinas 88 & 23.3 & 100 & 95.8 & 80.6 & 0.0007 \\
\hline Sniper & 25.8 & 100 & 91.7 & 72.9 & 0.0001 \\
\hline Pacific & 33.3 & 100 & 100 & 83.3 & 0.0073 \\
\hline Sundevil & 34.2 & 100 & 100 & 88.9 & 0.0397 \\
\hline$P$ & 0.9244 & 1.0000 & 0.5302 & 0.1063 & \\
\hline \multicolumn{6}{|l|}{ Romaine, Watsonville } \\
\hline Heart's Delight & $24.2 \mathrm{~d}$ & 94.4 & 98.6 & 93.1 & 0.4061 \\
\hline King Henry & $27.5 \mathrm{dc}$ & 93.1 & 100 & 83.3 & 0.0016 \\
\hline Camino Real & $44.2 \mathrm{bc}$ & 100 & 100 & 100 & 0.5542 \\
\hline Green Towers & $45.8 \mathrm{bc}$ & 100 & 100 & 93.1 & 0.1838 \\
\hline Darkland EL & $48.3 \mathrm{ab}$ & 100 & 100 & 94.4 & 0.332 \\
\hline USDA TBSVR line & $67.5 \mathrm{a}$ & 100 & 100 & 81.9 & 0.0001 \\
\hline$P$ & 0.004 & 0.3416 & 0.9993 & 0.0055 & \\
\hline
\end{tabular}

${ }^{\mathrm{y}}$ All values in the columns followed by the same letter were not significantly different within the same horticultural type either for disease incidence or for postharvest marketable heads. The $P$ value presented compares significance within a particular horticultural type.

${ }^{\mathrm{z}}$ The $P_{\mathrm{TIME}}$ values in the rows represent significant differences for postharvest marketable heads (\%) within a particular variety following 1,2 , or 3 weeks of storage. 
(week 1) evaluation was skipped because little tissue breakdown occurs at this time, as was the case for the romaine varieties in the Salinas field experiment.

Postharvest marketability evaluations. Postharvest marketability (the number of heads that are marketable, thus absent of any disorders and Verticillium symptoms) of leaf and butterhead lettuce at 1 and 2 weeks and of crisphead and romaine lettuce at 1 to 3 weeks after storage was evaluated by slicing all 24 heads (one box) longitudinally through the crown each week. Each head was carefully inspected visually for external and internal symptoms of any postharvest disorders of tipburn, brown stain, russet spots, pink rib, decay, and withering that makes heads unmarketable. The total number of plants showing no disorders were counted and converted to a percentage for the analysis.

Recovery of Verticillium species. The lettuce heads evaluated for postharvest marketability were inspected for the presence of vascular discoloration in the crown and stem tissues that resembled Verticillium wilt symptoms. Furthermore, crown tissue from each plant was plated to recover $V$. dahliae and non- $V$. dahliae $(V$. isaacii or $V$. klebahnii). Briefly, the crown tissues of each variety were surface sterilized, air dried under the hood, cut into four to five horizontal cross-sections, and placed on Petri plates containing NP-10 semiselective medium (Kabir et al. 2004). Plates were incubated at room temperature for 2 to 3 weeks to recover fungal species, and the total recovery percentage ( $=$ total number of symptomatic plants/total plants plated) was calculated. The recovery and identification of $V$. dahliae or non- $V$. dahliae ( $V$. isaacii and $V$. klebahnii) species was based on the morphological characteristics such as dark resting mycelia, chlamydospores, and distinctive yellow to orange pigmentation in culture (Inderbitzin et al. 2011).

Statistical analysis. All data for disease incidence, postharvest marketability, and recovery of Verticillium spp. were converted to percentages for statistical analyses using a generalized linear mixed model (PROC GLIMMIX) with the Kenward-Rogers degrees of freedom approximation in SAS version 9.3 (SAS Institute, Cary, NC). In all cases, varieties were grouped and analyzed by horticultural type (butterhead, red leaf, green leaf, romaine, and crisphead) with block and block $\times$ variety assessed as random effects in the model. In cases of repeated measures, such as evaluations for crisphead and romaine, a compound symmetry model was applied to the covariance structure. Mean separations among varieties within a horticultural type or among multiple time points were based on Fisher's protected least significant difference $(\alpha=0.05)$.

Pearson correlation coefficients $(r)$ were calculated using PROC CORR in SAS version 9.4, and plots were generated using Microsoft Excel. Average value of marketability and average percentage pathogen recovery across all weeks were used in the analysis as dependent variables for individual lettuce genotypes or horticultural types.

\section{Results}

Field disease incidence. Verticillium wilt incidence in lettuce at harvest maturity varied significantly between fields and within individual variety of each horticultural type (Fig. 1). In Salinas, the romaine type (Camino Real and Passport) had significantly lower disease incidence $(<30 \%)$ compared with crisphead type (Sniper and Salinas 88$)(>72 \%)$. Disease incidence did not differ statistically

Table 2. Analysis of variance of postharvest marketability among all horticultural lettuce types from two separate field experiments in Salinas and Watsonville, CA ( $P$ values associated with the different sources of variation are given)

\begin{tabular}{lcccccrrr}
\hline & \multicolumn{2}{c}{ Salinas } & & \multicolumn{3}{c}{ Watsonville } \\
\cline { 2 - 3 } Effect & Romaine & Crisphead & & Butterhead & Red leaf & Green leaf & Romaine & Crisphead \\
\hline Lettuce varieties & 0.6483 & 0.0014 & & 0.0385 & 0.1666 & 0.0104 & 0.0797 \\
Time & 0.0079 & 0.0020 & & 0.8518 & 0.8309 & 0.0398 & $<0.1556$ \\
Varieties $\times$ time & 0.5256 & 0.0007 & & 0.8518 & 0.5255 & 0.2025 & 0.1934 & 0.7538 \\
\hline
\end{tabular}

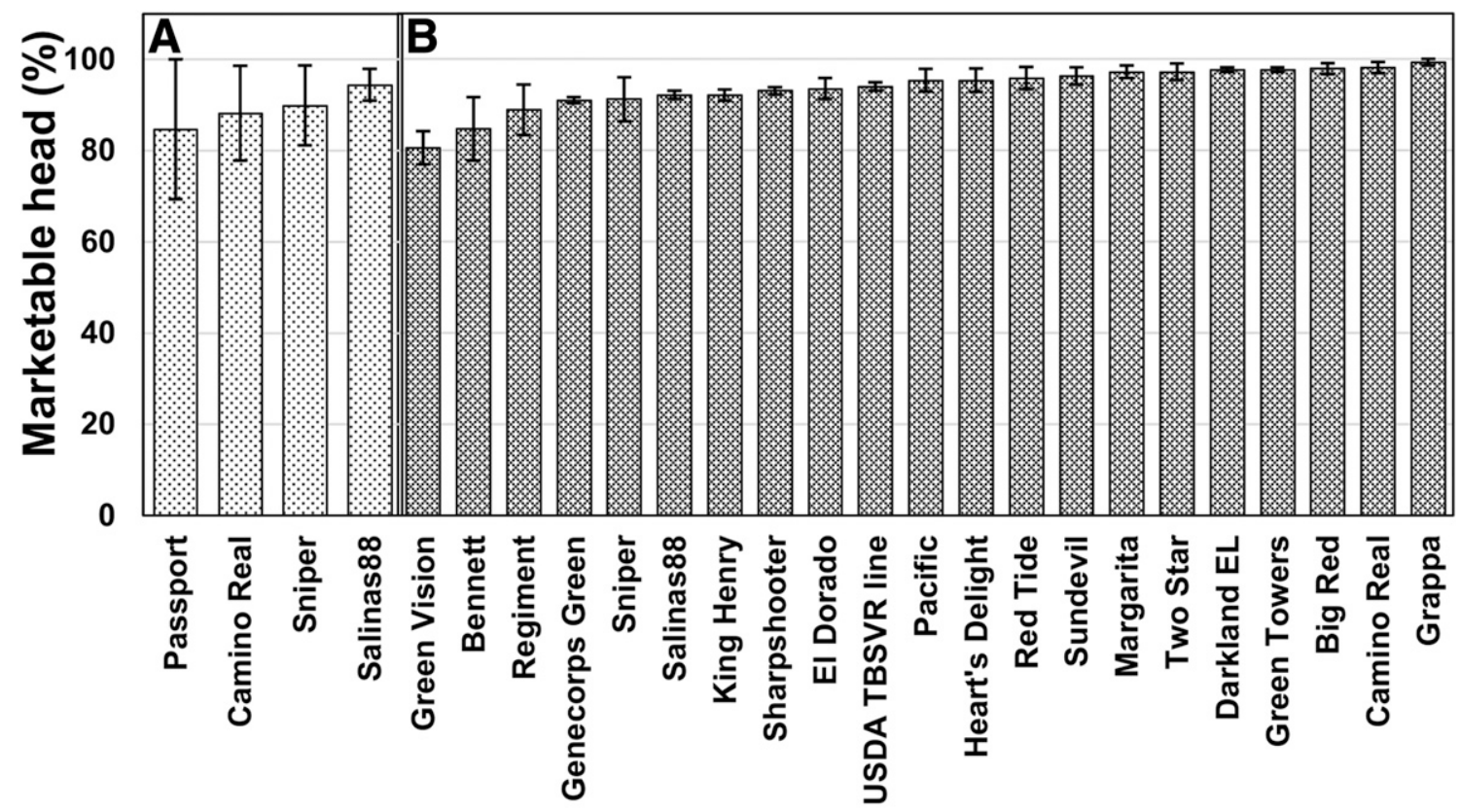

\section{Lettuce genotypes}

Fig. 2. Average percentage of marketable lettuce heads recovered after 2 or 3 weeks of refrigerated $\left(4^{\circ} \mathrm{C}\right)$ storage following harvest from the Salinas $(\mathbf{A})$ and Watsonville $(B)$ field sites. 
$(P=0.2999)$ between romaine varieties Camino Real and Passport but differed between the crisphead varieties Salinas 88 and Sniper $(P=0.0091)$ (Fig. 1A, Table 1)

In Watsonville, among all horticultural types compared, the butterhead and red leaf had significantly lower disease incidence $(<20 \%)$ compared with the crisphead and romaine types (Fig. 1B). A significant difference in disease incidence was detected among varieties

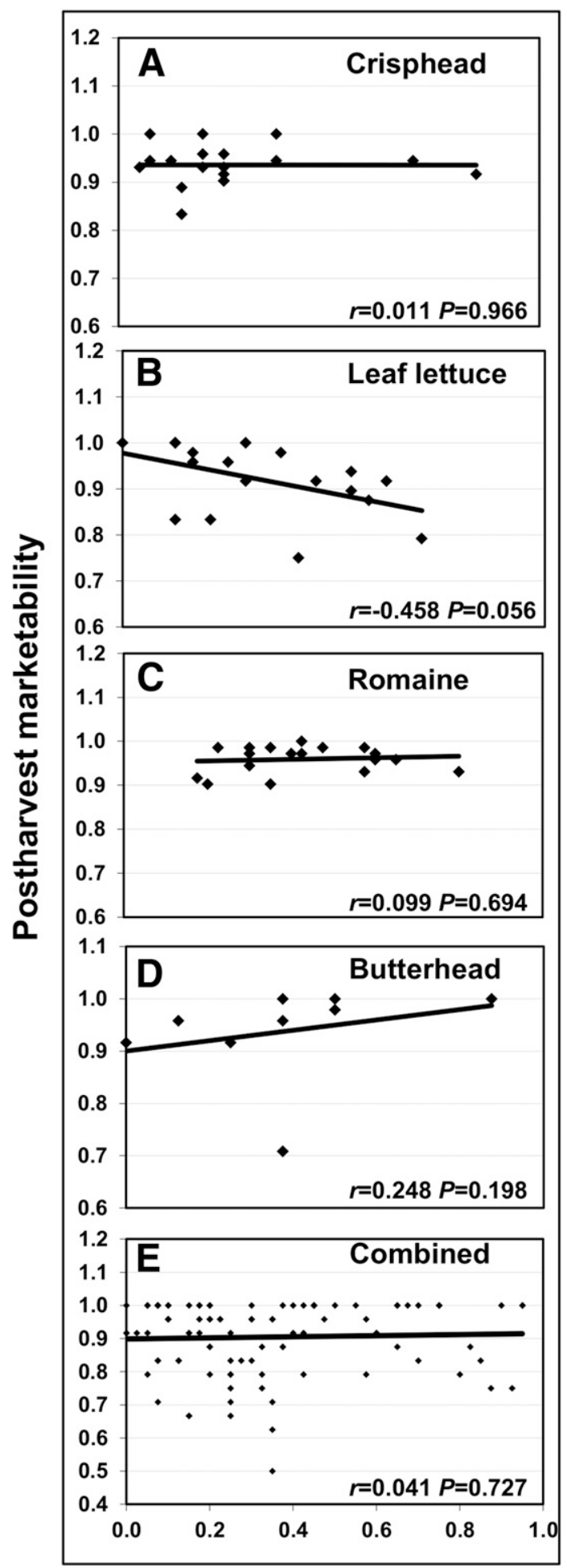

Field disease incidence

Fig. 3. Correlation of the proportion of field disease incidence to the proportion of postharvest marketability of all lettuce varieties in each horticultural type in Watsonville field experiment (A to $\mathbf{D}$ ), and combined field disease incidence and postharvest marketability of both experiments of the Salinas and Watsonville experimental sites $(\mathbf{E})$ within the red leaf and romaine type (Table 1); otherwise, varieties within a single horticultural type had no significant difference in disease incidence. Big Red (red leaf type), and Heart's Delight (romaine type) exhibited the lowest disease incidence within their respective horticultural type (Table 1). In contrast to the Salinas field experiment, the crisphead varieties Salinas 88 and Sniper exhibited lower disease incidence $(<26 \%)$ than the romaine variety Camino Real $(44.2 \%)$. The romaine USDA TBSVR line statistically exhibited the highest level of disease incidence (67.5\%) compared with remaining varieties in the Watsonville field location $(P=0.004)$.

Evaluation of postharvest marketability. Reduction in postharvest marketability over time was generally minimal in this experiment, but when it occurred it was dependent on lettuce variety and production location. No significant interaction between postharvest marketability and storage time was observed across all horticultural types, except for crisphead type in Salinas (Table 2). In Salinas, the crisphead variety Salinas 88 showed a significant reduction in postharvest marketability $(P<0.0001)$ from week 2 to week 3 , whereas the other crisphead variety, Sniper, did not $(P=0.5999)$ (Table 1).

In Watsonville, no significant interaction between storage time and postharvest marketability was detected for any horticultural type (Table 2). All crisphead (El Dorado, Sharpshooter, Salinas 88, Sniper, Pacific, and Sundevil), one green leaf (Genecorps Green), and two romaine (King Henry and USDA TBSVR line) varieties incurred a significant reduction in postharvest marketability from week 2 to week 3 of storage $(P<0.05$, Table 1$)$. In contrast, storage time had no statistically significant effect on postharvest marketability for all butterhead and red leaf varieties, two green leaf (Two Star and Green Vision), and four romaine (Heart's Delight, Camino Real, Green Towers, and Darkland EL) varieties during either first 2 or 3 weeks of storage $(P>0.05$, Table 1$)$. Some significant differences in postharvest marketability were observed among varieties within butterhead, green leaf, and romaine types at 1,2, and 3 weeks after storage, respectively $(P<0.05$, Table 1$)$, although these varietal differences were not consistent at all time points.

Further, no significant difference in the percent marketable heads was detected among the varieties stored at $4{ }^{\circ} \mathrm{C}$ and averaged across weeks (Fig. 2). Three varieties (Green Vision, Bennett, and Regiment) from Watsonville had relatively lower percentage of marketable heads but were not significantly different from other varieties (Fig. 2B). Big Red, Camino Real, and Grappa had highest postharvest marketability when averaged across weeks (Fig. 2B) in Watsonville. At least $69.4 \%$ of heads in Salinas and $72.9 \%$ of heads in Watsonville remained marketable at the third week of storage for any lettuce variety (Table 1).

Effect of field disease incidence on postharvest marketability. Pearson correlation $(r)$ indicated no dependence between field disease incidence and postharvest marketability for any variety. Combined analysis across all varieties indicated no significant correlation between field disease incidence and postharvest marketability in both Salinas and Watsonville experiments (data not shown). Postharvest marketability of varieties grouped based on horticultural type indicated a poor and nonsignificant association (Fig. $3 \mathrm{~A}$ to D). A negative and nonsignificant correlation $(r)$ existed within leaf lettuce ( $r=-0.457, P=0.056$, Fig. 3B), whereas all other lettuce types had a positive but nonsignificant $(P>0.05)$ correlation coefficient. The combined analysis of both experiments also indicated no dependence between postharvest marketability and field disease incidence ( $r=0.041, P=0.727$, Fig. 3E).

Postharvest recovery of Verticillium spp. The recovery of Verticillium species from the crown tissue varied from no recovery to 91.7\% for lettuce heads harvested from the Salinas field site (Fig. 4A) and 0 to $73.3 \%$ from the Watsonville field site (Fig. 4B). Interestingly, the non- $V$. dahliae ( $V$. isaacii or $V$. klebahnii) were recovered $(70.8$ to $97.7 \%$ ) more frequently than $V$. dahliae (0 to $4.2 \%$ ) from lettuce heads harvested in Salinas field site (Fig. 4A). However, no such variation existed in the retrieval of $V$. dahliae (0 to $73.3 \%$ ) and non- $V$. dahliae (10 to $66.7 \%$ ) from the Watsonville field site (Fig. 4B).

Regardless of the high variation in the recovery of $V$. dahliae and non- $V$. dahliae species among horticultural lettuce types, the 
variation was not as prominent among varieties within a single horticultural type except for green leaf type (Fig. 4B). Overall retrieval of Verticillium spp. was low $(<30 \%)$ in butterhead and red leaf varieties relative to the green leaf, crisphead, and romaine types that were grown at the Watsonville field site (Fig. 4B).
The frequency of $V$. dahliae or non- $V$. dahliae recovery had low dependence with field disease incidence, as suggested by the lack of significant correlation at 2 or 3 weeks of storage at $4^{\circ} \mathrm{C}$ of samples from Salinas $(P>0.05$, Fig. 5A). However, in Watsonville, relatively higher and significant correlation was observed between field disease

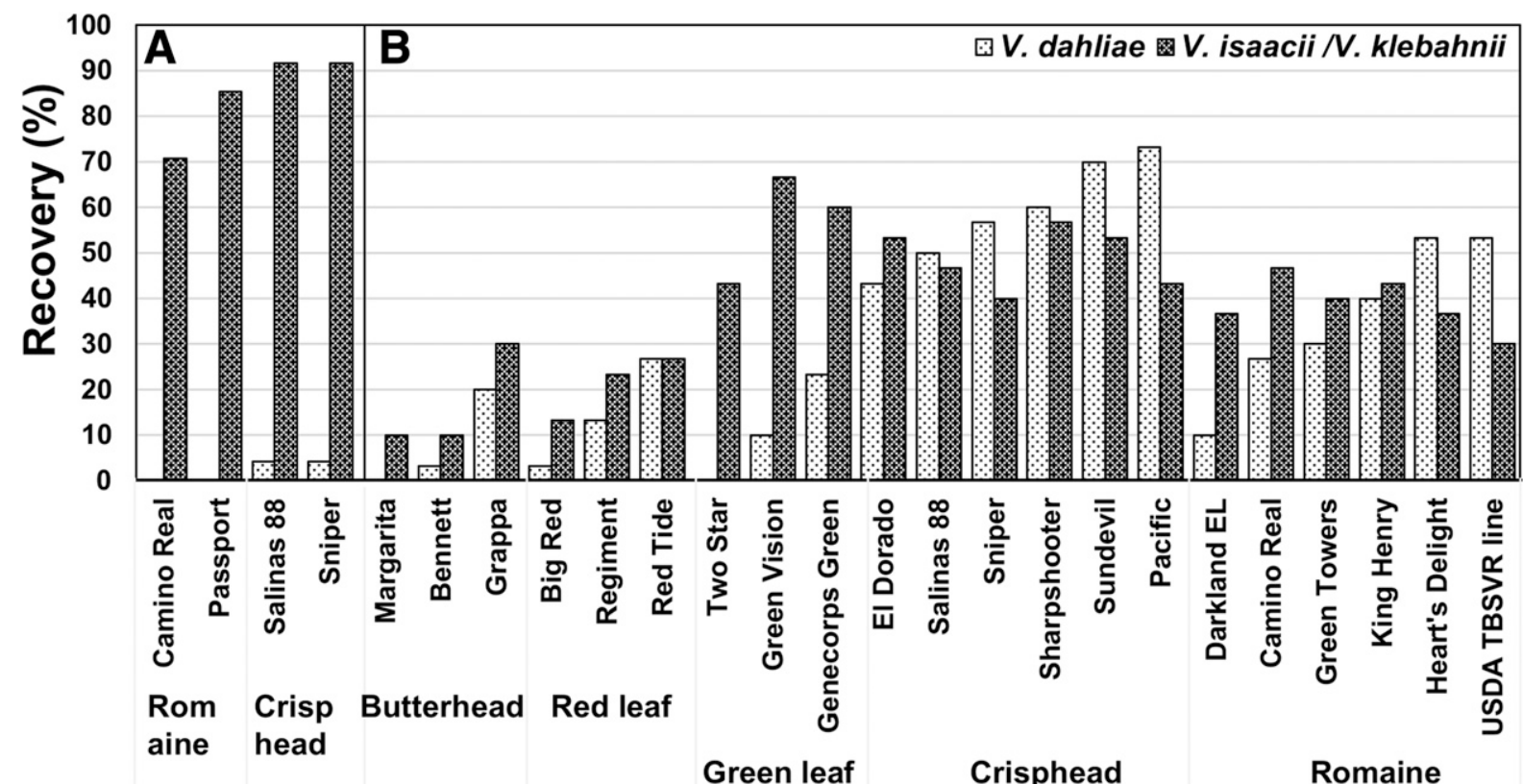

\section{Lettuce types}

Fig. 4. Recovery of Verticilium spp. from the crown tissue of all varieties, by horticultural lettuce type, harvested from the Salinas (A) and Watsonville (B) field sites.

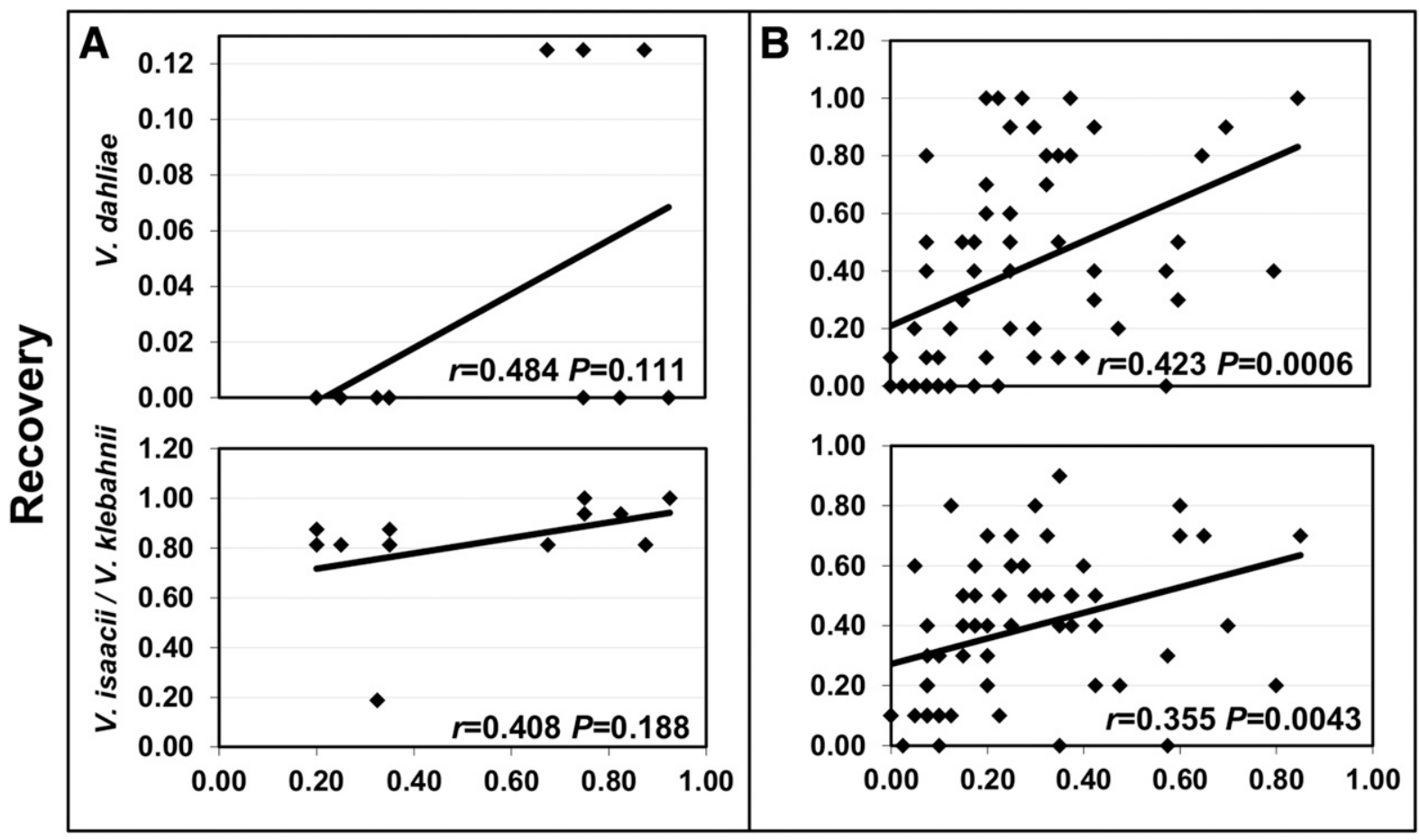

Field disease incidence

Fig. 5. Correlation of the proportion of Verticillium wilt incidence in the field prior to harvest to the average proportion of recovery of $V$. dahliae and $V$. isaacii/ $V$. klebahnii species from the crown tissue of varieties sampled in Salinas (A) and Watsonville (B) locations. 

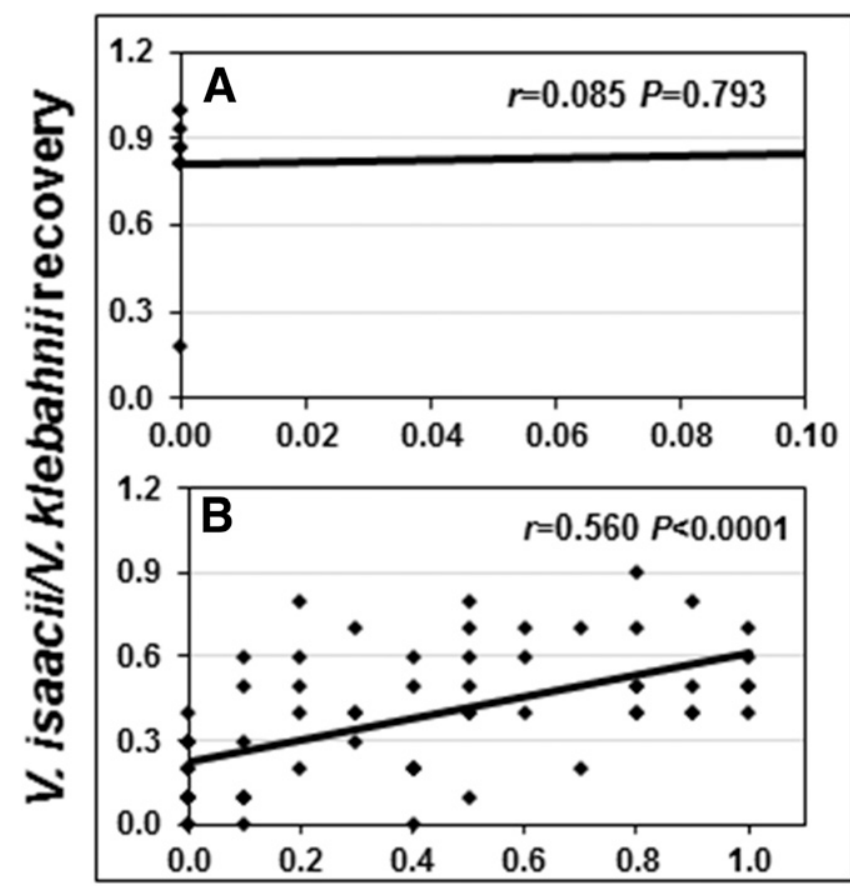

V. dahliae recovery

Fig. 6. Correlation between the proportion of recovery of Verticillium dahliae and $V$. isaacii/ . klebahnii from the lettuce crown at 3 weeks after storage at $4^{\circ} \mathrm{C}$ in Salinas (A) and Watsonville (B). incidence and $V$. dahliae $(r=0.423, P=0.0006)$ or non- $V$. dahliae recovery ( $r=0.355, P=0.0043$, Fig. $5 \mathrm{~B})$.

Although no significant relationship in the recovery of $V$. dahliae and non- $V$. dahliae species from lettuce crowns was detected $(r=$ $0.085, P=0.793$ ) at the Salinas site (Fig. 6A), a positive and a highly significant correlation $(r=0.560, P<0.001)$ occurred in Watsonville (Fig. 6B). Further, no relationship was observed between postharvest marketability and the recovery of Verticillium spp. for plants harvested from either Salinas (Fig. 7A) or Watsonville (Fig. 7B) field locations.

\section{Discussion}

Lettuce incurs a significant quality loss, as indicated by rib discoloration and decay owing to mechanical damage, fungal and bacterial infection, or physiological disorders (Gross et al. 2016; Schofield et al. 2005; Subbarao et al. 2017) in the absence of proper storage. Cold storage and modified-atmosphere packaging maintain extended postharvest marketability in lettuce (Hayes and Liu 2008). Previous studies on postharvest marketability focused on attributes such as texture, cell turgidity, water content, chlorophyll, visual quality, color, and enzymatic browning during postharvest storage of lettuce (Agüero et al. 2008; Hayes and Liu 2008; Heimdal et al. 1995; Hisaminato et al. 2001; Kim et al. 2005; Mateos et al. 1993; Tian et al. 2014). However, the impact of field disease incidence on postharvest disease progress and its correlation to quality loss remained obscure. This study monitored marketability and quality of lettuce heads of all major horticultural types harvested from Verticillium-infested fields during storage. Our study did not find evidence for Verticillium wilt progression during postharvest storage of asymptomatic marketable lettuce at least for 2 weeks for leaf and 3 weeks for crisphead or romaine lettuce. Factors such as time of transplanting, the timing of harvest, and crop maturity

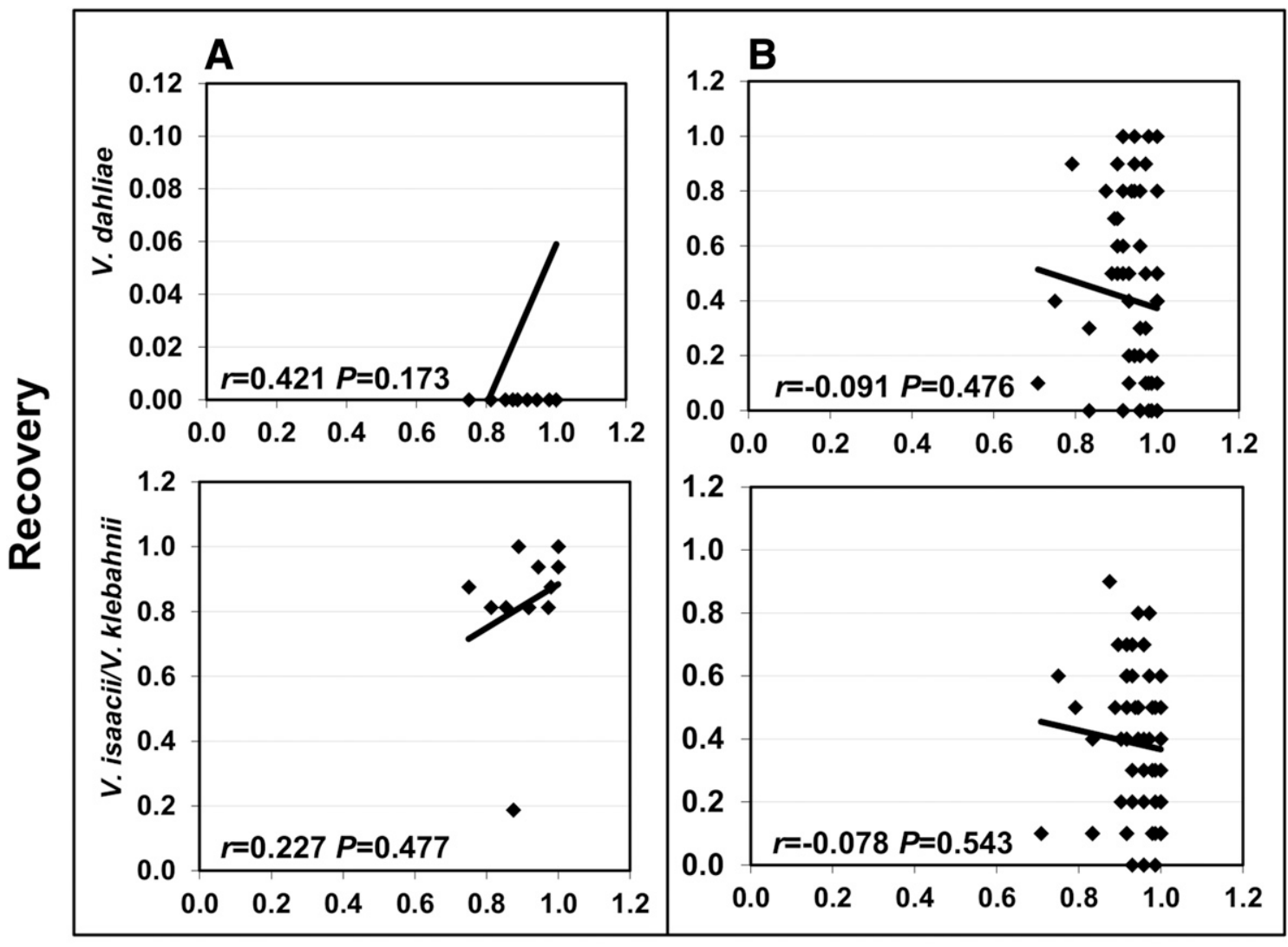

Post harvest marketability

Fig. 7. Correlation between proportion of postharvest marketability of all lettuce types and the proportion of the recovery of Verticillium dahliae and V. isaacii/V. klebahnii at 3 weeks after storage at $4^{\circ} \mathrm{C}$ in Salinas (A) and Watsonville (B) locations. 
may influence postharvest marketability of lettuce and should be considered in future studies.

Lettuce varieties evaluated in both field experiments showed significant variation in Verticillium wilt incidence. All 22 varieties were susceptible to Verticillium wilt to varying degrees (4.2 to $87.5 \%)$. The butterhead and red leaf types generally had a lower disease incidence than the romaine or green leaf types. All varieties except Sundevil (crisphead type) and the USDA TBSVR line (romaine type) were previously screened against Verticillium wilt in the field with similar findings to the present study (Hayes et al. 2007). The varieties Regiment and Two Star appeared resistant in prior field experiments but were susceptible to both races of $V$. dahliae in greenhouse studies (Hayes et al. 2007) and exhibited disease in the field experiment reported here. Varieties Red Tide, Big Red, Genecorps Green, and Sharpshooter exhibited relatively low disease incidence compared with previously reported field experiments (Hayes et al. 2007). The varying levels of disease incidence among varieties and horticultural types to Verticillium wilt is likely related to the variation in inoculum distribution within the field (Subbarao et al. 2017), the genetic variation among varieties for physiological development and susceptibility to $V$. dahliae, and interactions between host genetics and production environment (Hayes et al. 2007). Symptom development is related to plant development and progresses rapidly as the plant reaches vegetative maturity and begins reproductive growth (bolting) (Vallad et al. 2004). Therefore, disease evaluations at market maturity, which may not correspond to true vegetative maturity, can lead to misclassification of resistant plant materials (Hayes et al. 2007). This likely explains the higher susceptibility observed for crisphead varieties in the Salinas experiment, which was rated 77 days after planting, compared with the Watsonville experiment, which was rated at 70 days after planting. Lettuce heads must, therefore, be harvested at optimal maturity for longer shelf life (Chiesa et al. 2003) and reduced Verticillium wilt incidence. Immature lettuce exhibits shorter storage life and greater discoloration of the whole head than those heads harvested at optimum maturity (Barg et al. 2009). However, overmaturity may also result in reduced shelf life (Hayes and Liu 2008).

All varieties from the tested horticultural types had a higher number of marketable heads when stored in a commercial cooler for 2 weeks. However, a sharp and significant decline in marketable heads was found in all crisphead and two romaine varieties (King Henry and the USDA TBSVR line) after 2 weeks of storage. This indicates that a substantial decrease in shelf life can occur when lettuce is stored beyond 2 weeks, even in a commercial storage facility. Han et al. (2004) reported similar results in romaine lettuce, in which heads were degraded with mold when stored beyond 21 days at $4^{\circ} \mathrm{C}$. The variety, tissue age at the time of harvest, and maturity of heads at harvest had significant effects on lettuce shelf life, including the visual or organoleptic quality of salad-cut lettuce (Chiesa et al. 2003; Watada and Qi 1999). Lettuce crops grown during the cool season and stored in refrigeration after harvest resulted in a longer shelf life, good textural quality, and sugar and organic acid contents (Chandra et al. 2009). Remarkably, the romaine varieties tested in this study Heart's Delight, Camino Real, Green Towers, and Darkland EL had more than $93.1 \%$ marketable heads beyond 3 weeks of storage, even though the heads were harvested from a field with disease incidence above $45 \%$. The results on postharvest quality of harvested lettuce are consistent with those reported in the literature (Agüero et al. 2008, 2011; Atkinson et al. 2013).

Although $V$. dahliae is the primary cause of Verticillium wilt in lettuce in California (Subbarao et al. 1997), other Verticillium species (V. isaacii or V. klebahnii) were frequently recovered from lettuce heads harvested at both experimental sites. In the case of the Salinas site, these species were recovered at a greater frequency than $V$. dahliae, although the recovery of $V$. dahliae correlated with the disease incidence as expected. The higher recovery of non- $V$. dahliae species in the Salinas experiment site did not correlate with either the disease incidence or postharvest marketability.

The visibly symptomatic plants are never harvested in commercial fields and thus do not make it into the supply chain; that by itself minimizes the postharvest losses. Whether infected but asymptomatic plants harvested and shipped will suffer from either disease progression or related tissue breakdown during postharvest transit and storage was unknown thus far. Our study demonstrated that harvesting lettuce a few days before plant collapse even from severely infected fields is likely to maximize marketable crop yield and minimize subsequent postharvest losses owing to Verticillium wilt progression in storage. Thus, infection of field-harvested lettuce by Verticillium spp. neither progresses during postharvest storage or nor leads to a rapid decline in the quality of the produce beyond the shelf lives inherent to the different lettuce types.

\section{Acknowledgments}

We are grateful to the commercial growers that hosted the study and the Bengard cooling facility, which allowed us to store and retrieve the harvested lettuce for evaluation.

\section{Literature Cited}

Agüero, M. V., Barg, M. V., Yommi, A., Camelo, A., and Roura, S. I. 2008. Postharvest changes in water status and chlorophyll content of lettuce (Lactuca sativa L.) and their relationship with overall visual quality. J. Food Sci. 73:S47-S55

Agüero, M. V., Ponce, A. G., Moreira, M. R., and Roura, S. I. 2011. Lettuce quality loss under conditions that favor the wilting phenomenon. Postharvest Biol. Technol. 59:124-131.

Atallah, Z. K., Hayes, R. J., and Subbarao, K. V. 2011. Fifteen years of Verticillium wilt of lettuce in America's salad bowl: A tale of immigration, subjugation, and abatement. Plant Dis. 95:784-792.

Atallah, Z. K., Maruthachalam, K., and Subbarao, K. V. 2012. Sources of Verticillium dahliae affecting lettuce. Phytopathology 102:1071-1078.

Atkinson, L. D., Hilton, H. W., and Pink, D. A. C. 2013. A study of variation in the tendency for postharvest discoloration in a lettuce (Lactuca sativa) diversity set. Int. J. Food Sci. Technol. 48:801-807.

Barg, M., Aguero, M. V., Yommi, A., and Roura, S. I. 2009. Evolution of plant water status indices during butterhead lettuce growth and its impact on poststorage quality. J. Sci. Food Agric. 89:422-429.

Cantwell, M., and Suslow, T. 2002. Lettuce, Crisphead. Recommendations for Maintaining Postharvest Quality. Department of Plant Sciences, University of California, Davis

Chandra, D., Matsui, T., Suzuki, H., Kosugi, Y., Fujimura, K., and Bhowmik, P. K. 2009. Textural and compositional changes of stored iceberg lettuce in relation to harvest season and storage condition. Int. J. Veg. Sci. 16:44-59.

Chiesa, A., Frezza, D., Fraschina, A., Trinchero, G., Moccia, S., and Leon, A. 2003. Pre-harvest factors and fresh-cut vegetables quality. Acta Hortic. 604: 153-159.

Cirulli, M., Bubici, G., Amenduni, M., Armengol, J., Berbegal, M., JiménezGasco, M. M., and Jiménez-Díaz, R. M. 2010. Verticillium wilt: A threat to artichoke production. Plant Dis. 94:1176-1187.

Gross, K. C., Wang, Y. C., and Saltveit, M. 2016. Lettuce. Pages 386-389 in: The Commercial Storage of Fruits, Vegetables, and Florist and Nursery Stocks. Agriculture Handbook No. 66. U.S. Department of Agriculture, Washington DC.

Gurung, S., Short, D. P. G., Hu, X., Sandoya, G. V., Hayes, R. J., Koike, S. T., and Subbarao, K. V. 2015. Host range of Verticillium isaacii and Verticillium klebahnii from artichoke, spinach, and lettuce. Plant Dis. 99:933-938.

Han, J., Gomes-Feitosa, C. L., Castell-Perez, E., Moreira, R. G., and Silva, P. F. 2004. Quality of packaged romaine lettuce hearts exposed to low-dose electron beam irradiation. Lebensm. Wiss. Technol. 37:705-715.

Harvey, J. M. 1978. Reduction of losses in fresh market fruits and vegetables Annu. Rev. Phytopathol. 16:321-341.

Hayes, R. J. 2017a. Introduction. Pages 1-6 in: Compendium of Lettuce Diseases, 2nd Ed. K. V. Subbarao, R. M. Davis, R. L. Gilbertson, and R. N. Raid, eds. American Phytopathological Society, St. Paul, MN.

Hayes, R. J. 2017b. Noninfectious physiological disorders. Pages 120-123 in: Compendium of Lettuce Diseases, 2nd Ed. K. V. Subbarao, R. M. Davis, R. L. Gilbertson, and R. N. Raid, eds. American Phytopathological Society, St. Paul, MN.

Hayes, R. J., and Liu, Y. B. 2008. Genetic variation for shelf-life of salad-cut lettuce in modified-atmosphere environments. J. Am. Soc. Hortic. Sci. 133:228-233.

Hayes, R. J., Vallad, G. E., Qin, Q. M., Grube, R. C., and Subbarao, K. V. 2007. Variation for resistance to Verticillium wilt in lettuce (Lactuca sativa L.). Plant Dis. 91:439-445

Heaton, J. C., and Jones, K. 2008. Microbial contamination of fruit and vegetables and the behavior of enteropathogens in the phyllosphere: A review. J. Appl Microbiol. 104:613-626.

Heimdal, H., Kuhn, B. F., Poll, L., and Larsen, L. M. 1995. Biochemical changes and sensory quality of shredded and MA-packaged iceberg lettuce. J. Food Sci. 60:1265-1268.

Hisaminato, H., Murata, M., and Homma, S. 2001. Relationship between the enzymatic browning and phenylalanine ammonia-lyase activity of cut lettuce, 
and the prevention of browning by inhibitors of polyphenol biosynthesis. Biosci. Biotechnol. Biochem. 65:1016-1021.

Inderbitzin, P., Bostock, R. M., Davis, R. M., Usami, T., Platt, H. W., and Subbarao, K. V. 2011. Phylogenetics and taxonomy of the fungal vascular wilt pathogen Verticillium, with the descriptions of five new species. PLoS One 6:e28341.

Kabir, Z., Bhat, R. G., and Subbarao, K. V. 2004. Comparison of media for recovery of Verticillium dahliae from soil. Plant Dis. 88:49-55.

Kader, A. A. 2005. Increasing food availability by reducing postharvest losses of fresh produce. Acta Hortic. 682:2169-2176.

Kim, J. G., Luo, Y. G., Tao, Y., Saftner, R. A., and Gross, K. C. 2005. Effect of initial oxygen concentration and film oxygen transmission rate on the quality of fresh-cut romaine lettuce. J. Sci. Food Agric. 85:1622-1630.

Leff, J. W., and Fierer, N. 2013. Bacterial communities associated with the surfaces of fresh fruits and vegetables. PLoS One 8:e59310.

Lin, W. C., and Hall, J. W. 2003. Shelf life of greenhouse lettuce affected by growing and postharvest conditions. Acta Hortic. 628:129-134.

Liu, Y. B. 2017. Postharvest diseases and disorders. Pages 136-137 in: Compendium of Lettuce Diseases, 2nd Ed. K. V. Subbarao, R. M. Davis, R. L. Gilbertson, and R. N. Raid, eds. American Phytopathological Society, St. Paul, MN

Martínez-Sánchez, A., Luna, M. C., Selma, M. V., Tudela, J. A., Abad, J., and Gil, M. I. 2012. Baby-leaf and multi-leaf of green and red lettuces are suitable raw materials for the fresh-cut industry. Postharvest Biol. Technol. 63:1-10.

Mateos, M., Ke, D., Cantwell, M., and Kader, A. A. 1993. Phenolic metabolism and ethanolic fermentation of intact and cut lettuce exposed to $\mathrm{CO}_{2}$-enriched atmospheres. Postharvest Biol. Technol. 3:225-233.

Moline, H. E., and Lipton, W. J. 1987. Market Diseases of Beets, Chicory, Endive, Escarole, Globe Artichokes, Lettuce, Rhubarb, Spinach, and Sweetpotatoes. Agriculture Handbook No. 155. U.S. Department of Agriculture, Washington, DC.

Nam, S. Y., and Kwon, Y. W. 1999. Quality changes of hydroponically produced leaf lettuce (Lactuca sativa L., cv. Cheongchima) during postharvest storage. Acta Hortic. 483:173-184.

Powell, M., Gundersen, B., Miles, C., Coats, K., and Inglis, D. A. 2013. First report of Verticillium wilt on lettuce (Lactuca sativa) in Washington caused by Verticillium tricorpus. Plant Dis. 97:996.

Qin, Q. M., Vallad, G. E., and Subbarao, K. V. 2008. Characterization of Verticillium dahliae and V. tricorpus isolates from lettuce and artichoke. Plant Dis. 92:69-77.

Raid, R. N. 2004. Lettuce diseases and their management. Pages 121-147 in: Diseases of Fruits and Vegetables: Vol. II. S. A. M. H. Naqvi, ed. Kluwer Academic Publishers, Dordrecht, the Netherlands.
Saltveit, M. E., Smith, R. F., and Liu, Y. B. 2017. Postharvest diseases and disorders. Pages 139-140 in: Compendium of Lettuce Diseases, 2nd Ed. K. V. Subbarao, R. M. Davis, R. L. Gilbertson, and R. N. Raid, eds. American Phytopathological Society, St. Paul, MN.

Schofield, R. A., DeEll, J. R., Murr, D. P., and Jenni, S. 2005. Determining the storage potential of iceberg lettuce with chlorophyll fluorescence. Postharvest Biol. Technol. 38:43-56.

Short, D. P. G., Gurung, S., Koike, S. T., Klosterman, S. J., and Subbarao, K. V. 2015. Frequency of Verticillium species in commercial spinach fields and transmission of $V$. dahliae from spinach to subsequent lettuce crops. Phytopathology 105:80-90.

Smith, P., Polomski, B., and Shaughnessy, D. 2003. Lettuce. Factsheet HGIC 1312. Clemson University Cooperative Extension Service, Clemson, SC.

Subbarao, K., Hubbard, J. C., Greathead, A. S., and Spencer, G. A. 1997. Verticillium wilt. Pages 26-27 in: Compendium of Lettuce Diseases. R. M. Davis, K. V. Subbarao, R. N. Raid, and E. A. Kurtz, eds. American Phytopathological Society, Paul, MN.

Subbarao, K. V., Davis, R. M., Gilbertson, R. L., and Raid, R. N., eds. 2017 Compendium of Lettuce Diseases. American Phytopathological Society, Saint Paul, MN.

Tian, W., Lv, Y., Cao, J., and Jiang, W. 2014. Retention of iceberg lettuce quality by low-temperature storage and postharvest application of 1-methylcyclopropene or gibberellic acid. J. Food Sci. Technol. 51:943-949.

Vallad, G. E., Qin, Q.-M., Grube, R., Hayes, R. J., and Subbarao, K. V. 2006. Characterization of race-specific interactions among isolates of Verticillium dahliae pathogenic on lettuce. Phytopathology 96:1380-1387.

Vallad, G. E., Qin, Q.-M., and Subbarao, K. V. 2004. Verticillium wilt of cool season vegetable crops: Their distribution, impact and management. Pages 189-210 in: Recent Research Developments in Plant Pathology. S. G. Pandalai, ed. Vol. 3. Research Signpost, Trivandrum, India.

Vallad, G. E., and Subbarao, K. V. 2008. Colonization of resistant and susceptible lettuce cultivars by a green fluorescent protein-tagged isolate of Verticillium dahliae. Phytopathology 98:871-885.

Wagstaff, C., Clarkson, G. J. J., Zhang, F. Z., Rothwell, S. D., Fry, S. C., Taylor G., and Dixon, M. S. 2010. Modification of cell wall properties in lettuce improves shelf life. J. Exp. Bot. 61:1239-1248.

Watada, A. E., and Qi, L. 1999. Quality of fresh-cut produce. Postharvest Biol. Technol. 15:201-205.

Zhang, F. Z., Wagstaff, C., Rae, A. M., Sihota, A. K., Keevil, C. W., Rothwell, S D., Clarkson, G. J., Michelmore, R. W., Truco, M. J., Dixon, M. S., and Taylor, G. 2007. QTLs for shelf life in lettuce co-locate with those for leaf biophysical properties but not with those for leaf developmental traits. J. Exp. Bot. 58: 1433-1449. 